\title{
A Revista Brasileira de Geriatria e Gerontologia na SciELO: uma trajetória bem-sucedida no campo do envelhecimento
}

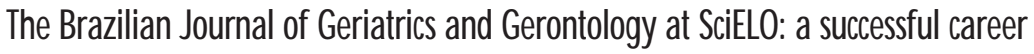 \\ inthefieddof aging
}

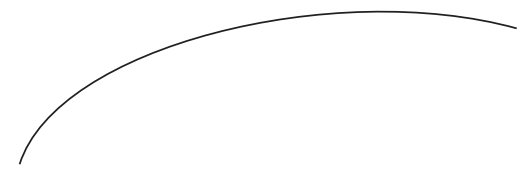

A Revista Brasileira de Geriatria e Gerontologia (RBGG), publicação especializada no tema do envelhecimento humano editada pela UnATI/UERJ tem, mais uma vez, muito a comemorar. Há bem pouco tempo, estávamos felizes pela ampliação da abrangência da revista, pelo fato de estarmos recebendo manuscritos de pesquisadores de vários estados brasileiros e do exterior, e por percebermos a importância da RBGG na ampliação do debate em tópico tão relevante para o país, consequência da extensão do tempo de vida.

Hoje comemoramos um novo e alvissareiro acontecimento. A RBGG foi selecionada para participar do seleto grupo de periódicos científicos brasileiros pertencentes à SciELO - Scientific Electronic Library Online. Para aqueles menos familiarizados com a área, a SciELO é um projeto científico que conta com o apoio de importantes agências de fomento em países da América Latina e Caribe, e que tem por objetivo o desenvolvimento de uma metodologia comum para preparação, armazenamento, disseminação e avaliação da produção científica em formato eletrônico. Pelo fato de ser uma biblioteca eletrônica, oferece a todos os pesquisadores um amplo acesso a coleções e fascículos de cada título de periódico, assim como aos textos completos dos artigos. E é sempre bom frisar: das melhores e mais qualificadas publicações científicas nacionais e internacionais.

Se no momento estamos comemorando esta importante conquista, sabemos que permanecer como membros do SciELO significa qualificarmos ainda mais a RBGG, pois a partir de agora seu alcance se amplia de modo geométrico.

Desejamos e iremos manter nossa política de uma revista ampla e abrangente, que cubra os mais diversos temas da nova fase da vida que é o envelhecimento, na qual a discussão não esteja limitada a questões específicas. Ou seja, entendemos a RBGG como um periódico de Saúde Pública Gerontológica, e que, por seu ineditismo, precisa buscar sempre o rigor metodológico e a qualidade de seus artigos e se situar como uma das importantes revistas científicas brasileiras. Mais um passo foi dado nessa direção! 